\title{
PEMANFAATAN LEARNING MANAGEMENT SYSTEM DALAM PROSES PEMBELAJARAN MATEMATIKA DISKRIT
}

\author{
Novi Mardiana', Ahmad Faqih ${ }^{2)}$ \\ ${ }^{1) 2)}$ STMIK IKMI Cirebon,Jln Perjuangan No.10B Majasem Kota Cirebon \\ nov.mardiana@gmail.com ${ }^{1)}$, faqih.ahmad@gmail.com ${ }^{2)}$
}

\begin{abstract}
This paper presents the results related to the influence of Mathematics Ability variables and Application-Computer Self-Efficacy (ACSE) students on the Quality of Learning Outcomes in the process of learning Discrete Mathematics by utilizing LMS as a support system. The research method used is Classroom Action Research (CAR), using a quantitative approach. Respondents were third semester students of the Informatics Engineering study program STMIK IKMI Cirebon. The research data were obtained from observations, questionnaires, databases of grades of Calculus and Linear Algebra courses, and recapitulation of student learning outcomes for one semester in Discrete Mathematics lectures. Data analysis was performed using the Dummy Regression method. Based on data analysis, it was found that Mathematical Ability and Application-Computer Self-Efficacy (ACSE) of students had a positive effect on the quality of the results of Discrete Mathematics learning using LMS as a support system.

Keywords: Application-Computer Self-Efficacy (ACSE), Learning Management System (LMS), Dummy Regression.
\end{abstract}

\begin{abstract}
ABSTRAK
Paper ini menyajikan hasil terkait pengaruh variabel Kemampuan Matematika dan Application-Computer Self-Efficacy (ACSE) mahasiswa terhadap Kualitas Hasil Belajar pada proses pembelajaran Matematika Diskrit dengan memanfaatkan LMS sebagai sistem pendukung. Metode penelitian yang digunakan adalah Penelitian Tindakan Kelas (PTK), dengan menggunakan pendekatan kuantitatif. Responden adalah mahasiswa semester 3 program studi Teknik Informatika STMIK IKMI Cirebon. Data penelitian diperoleh dari pengamatan, penyebaran kuisoner, database nilai mata kuliah Kalkulus dan Aljabar Linier, dan rekapitulasi hasil belajar mahasiswa selama satu semester pada perkuliahan Matematika Diskrit. Analisa data dilakukan menggunakan metode Regresi Dummy. Berdasarkan analisa data diperoleh bahwa Kemampuan Matematika dan Application-Computer Self-Efficacy (ACSE) mahasiswa berpengaruh positif terhadap kualitas hasil akhir pembelajaran Matematika Diskrit yang menggunakan LMS sebagai sistem pendukung.
\end{abstract}

Kata kunci: Application-Computer Self-Efficacy (ACSE), Learning Management System (LMS), Dummy Regression 


\section{PENDAHULUAN}

Kompetensi adalah pola yang dapat diukur berupa pengetahuan, skill, kemampuan, perilaku dan sederet karakteristik laian yang dibutuhkan seorang individu untuk menunjukkan dengan berhasil performa atau fungsi kerjanya (Sturgess, 2012). Kompetensi lulusan prodi Teknik Informatika dapat dilihat salah satunya berdasarkan kualitas hasil belajar mereka selama menempuh pendidikan. Fondasi utama ketercapaian kompetensi tersebut adalah penguasaan logika, kemampuan berpikir sistematis dan kemampuan pemecahan masalah. Ketiga hal mendasar ini dipelajari dan dilatih dalam mata kuliah-mata kuliah matematika. Matematika sebagai sebuah ilmu dasar mengajarkan bagaimana seseorang mampu berpikir secara sistematis, logis, cermat, konsisten, kreatif dan inovatif.

Dalam kurikulum prodi Teknik Informatika STMIK IKMI Cirebon setidaknya terdapat 4 mata kuliah matematika yaitu Kalkulus, Aljabar Linier dan Matriks, Matematika Diskrit, dan Metode Numerik. Mata kuliah matematika yang terkait langsung dengan informatika adalah Matematika Diskrit sebagai fondasi utama teori-teori ilmu komputer dimana objek-objek diskrit dan logika matematika dipelajari. Objek diskrit merupakan semesta pembicaraan dalam ilmu komputer. Logika matematika adalah alat yang sangat ampuh untuk penalaran terhadap berbagai masalah yang tampaknya tidak saling berkaitan. Minimnya pemahaman materi-materi Matematika Diskrit berakibat pada hilangnya inti dari logika dalam memahami teori-teori dasar ilmu komputer. Kondisi tersebut berimplikasi terhadap ketercapaian kompetensi bidang komputer. Sehingga diperlukan penguasaan materi-materi dalam Matematika Diskrit dengan baik dan menyeluruh. Sayangnya, sebagian besar mahasiswa kesulitan memahami dan menguasai materi-materi tersebut.

Kendala yang dihadapi antara lain karena kemampuan matematika yang kurang, rendahnya minat belajar matematika, persepsi tentang sulitnya matematika untuk dipelajari, rendahnya wawasan mahasiswa tentang kaitan matamatika dengan masalah dalam kehidupan nyata.

$$
\text { Dalam rangka mengatasi }
$$
masalah kesulitan belajar matematika para mahasiswa, oleh dosen sudah diterapkan beberapa metode dan model pembelajaran dalam sesi pembelajaran. Namun,hal tersebut belum secara siginifikan menyelesaikan masalah. Dengan demikian, diperlukan sebuah inovasi pembelajaran yang diharapkan dapat meningkatkan kualitas proses pembelajaran yang berimplikasi pada minat belajar dan kualitas hasil belajar mahasiswa pada perkuliahan matematika.

Inovasi dapat dilakukan dengan melibatkan perkembangan teknologi dalam hal ini adalah Learning Management System (LMS), dalam proses pembelajaran Matemtaika Diskrit. LMS digunakan sebagai sistem 
pendukung proses pembelajaran, bukan sebagai pengganti sesi tatap muka. Saat ini telah tersedia banyak platform LMS open source yang dapat dimodifikasi fitur dan interfacenya sesuai dengan kebutuhan dan karakterirstik user dalam hal ini perguruan tinggi. LMS yang digunakan dalam penelitian ini berbasis Chamilo dengan alamat http://stmikikmi-cirebon.net/indigoes/. LMS ini telah dibangun dan digunakan di lingkungan STMIK IKMI Cirebon dalam beberapa tahun terakhir.

Menurut (Coates. dkk, 2005), LMS dapat didefinisikan sebagai suatu sistem berbasis internet yang mengintegrasikan antara pedagogik dan administrasi pembelajaran. (Ayub.dkk, 2010), menyatakan LMS adalah sebuah sistem teknologi berbasis web yang dapat membantu perencanaan, distribusi dan evaluasi proses pembelajaran. Pada beberapa penelitian sebelumnya ditunjukkan bahwa LMS dalam proses pembelajaran memiliki hubungan yang erat dengan kualitas hasil belajar. (Stith, 2000) dalam penelitiannya menyatakan bahwa LMS mampu meningkatkan keterlibatan peserta didik dalam proses pembelajaran dan memperdalam pengalaman belajar peserta didik (Carmean \& Haefner, 2002).

Tujuan penelitian ini untuk melihat seberapa besar variabel-variabel independen berpengaruh terhadap kualitas hasil belajar mahasiswa yang menggunakan LMS dalam proses belajar Matematika Diskrit. Variabel yang dimaksud mempengaruhi kualitas tersebut adalah kemampuan matematika, application-computer self- efficacy, dan latar belakang pendidikan menengah.

\section{LANDASAN/KAJIAN TEORI}

\section{Learning Management System}

Learning management system atau LMS adalah sebuah alat untuk menunjang e-learning. LMS adalah paket perangkat lunak yang digunakan untuk mengelola satu atau lebih kursus ke satu atau lebih peserta didik. LMS dapat digambarkan sebagai suatu sistem perangkat lunak berbasis server yang digunakan untuk mengelola pembelajaran dan mengirimkan semua materi dengan berbagai jenis bentuk data baik berupa teks, audio maupun video.

(Baragash \& Al-Samarraie, 2018) telah mengkaji hubungan keterlibatan mahasiswa pada model pembelajaran dengan LMS, tatap muka dan berbasis website terhadap performa mahasiswa diakhir proses pembelajaran. Berdasarkan analisa data diperoleh kesimpulan bahwa LMS secara positif berpengaruh terhadap performa mahasiswa. Penelitian (Williams \& Whiting, 2016) mengkaji hubungan LMS, Twitter, dengan keterlibatan mahasiswa dalam pembelajaran.

\section{Matematika Diskrit}

Matematika Diskrit adalah cabang matematika yang membahas segala sesuatu yang bersifat diskrit. Matematika Diskrit adalah matematika yang khas informatika sehingga mata kuliah ini menjadi mata kuliah penting di program studi Teknik Informatika. Mata kuliah ini berisi materi-materi mendasar yang harus dipahami dan 
dikuasai sebagai fondasi mata kuliah bidang teknologi informasi.

Konsep dan notasi dari materimateri Matematika Diskrit berguna dalam mempelajari dan menggambarkan objek dan permasalahan di cabang ilmu komputer, seperti algoritma komputer, bahasa pemrograman, kriptografi, data mining, keamanan jaringan dan pengembangan perangkat lunak.

\section{Kualitas Pembelajaran}

Degeng, (2004) menyatakan kualitas pembelajaran dapat diartikan sebagai suatu kondisi yang menggambarkan tingkat efektivitas suatu pembelajaran. Pembelajaran yang efektif adalah pembelajaran yang mampu menfasilitasi peserta didik untuk aktif terlibat dengan berbagai sumber belajar sehingga peserta didik mencapai tujuan-tujuan pembelajaran secara efektif, efisien, dan menyenangkan (berdaya tarik). Peningkatan kualitas pembelajaran berarti upaya-upaya yang dilakukan dalam mewujudkan dan meraih tingkat kualitas pembelajaran yang diharapkan. Kualitas pembelajaran dapat dilihat dari dua segi, yaitu: segi proses dan segi hasil pembelajaran. Peningkatan kualitas pembelajaran dari segi proses adalah upaya-upaya untuk memperbaiki kualitas proses pembelajaran yang mengarah kepada terjadinya prakarsa belajar oleh peserta didik. Salah satu upaya yang dapat dilakukan adalah inovasi menggunakan LMS dalam proses pembelajaran.

\section{Self efficacy}

(Usta dkk, 2014) mengaitkan preferensi belajar mahasiswa yang dalam proses pembelajarannya menggunakan LMS ternyata menentukan keberhasilan atau pencapaian akademik. Indikator yang digunakan untuk melihat kualitas hasil belajar adalah nilai akhir mahasiswa pada akhir proses pembelajaran. Salah satu hal yang penting dalam pemanfaatan LMS oleh mahasiswa adalah kemampuan mahasiswa terlibat aktif dan nyaman terhadap system tersebut.

Self-Efficacy adalah persepsi atau penilaian diri sendiri mengenai seberapa baik dirinya berfungsi dalam sebuah situasi tertentu (Bandura, 1994). (Marakas, G.M. dkk, 1998), membagi computer self efficacy (CSE) menjadi dua yaitu level penguasaan komputasi secara umum dan level penguasaan aplikasi tertentu. Application-specific self-efficacy adalah persepsi seseorang terhadap kemampuannya menggunakan aplikasi atau sistem tertentu.

(Yi \& Hwang, 2003) menyatakan application-specific selfefficacy memiliki efek yang posisitif terhadap persepsi user atas kemudahan penggunaan sebuah sistem. Berdasarkan definisi TAM (Technology Acceptance Model) , kemudahan mahasiswa terhadap sebuah sistem akan membuat mahasiswa merasa nyaman dan secara kontinu mau menggunakan sistem tersebut. Persepsi kemudahan ini diharapkan mampu meningkatkan minat dalam mengakses dan menggunakan semua fitur yang ada pada LMS.

\section{Kemampuan Matematika}

Kemampuan matematika seseorang berpengaruh kuat terhadap self-efficacy seseorang ketika 
mempelajari matematika. (Karsenty, 2014) mendefinisikan kemampuan matematika sebagai kemampuan seseorang untuk menyelesaikan tugas matematika dan secara efektif memberikan solusi dari masalah matematika. Kemampuan matematika adalah kapasitas seseorang untuk mempelajari dan menguasai ide dan skill matematis yang baru (Koshy.dkk, 2009). Secara pragmatis definisi tersebut dapat digunakan dalam rangka evaluasi kualitas hasil belajar dan mengidentifikasi kemampuan awal mahasiswa dalam matematika.

\section{METODE PENELITIAN}

Berikut dijabarkan berbagai hal terkait metode penelitian dalam artikel ini.

\section{Jenis Penelitian}

Metode penelitian yang digunakan adalah Penelitian Tindakan Kelas (PTK). dengan menggunakan pendekatan kuantitatif. Tindakan atau intervensi yang digunakan berupa penggunaan LMS sebagai sistem pendukung dalam proses pembelajaran Matematika Diskrit.

\section{Waktu dan Tempat Penelitian}

Penelitian dilakukan selama satu semester di Prodi Teknik Informatika STMIK IKMI Cirebon pada perkuliahan Matematika Diskrit tahun ajaran 2018/2019.

\section{Populasi Penelitian}

Observasi dan pengambilan data dilakukan terhadap mahasiswa semester 3 Prodi Teknik Informatika STMIK IKMI Cirebon yang mengikuti perkuliahan Matematika Diskrit pada dan menggunakan LMS dalam proses pembelajaran. Mahasiswa yang dimaksud adalah mahasiswa kelas regular pagi. Pada penelitian ini sampel sama dengan populasi yang telah ditentukan diawal penelitian.

\section{Prosedur}

Pemanfaatan LMS dilakukan sejak pertemuan awal perkuliahan. LMS digunakan untuk mendistribusikan konten pembelajaran berupa modul, slide presentasi, buku soal dan video pembelajaran. Selain itu LMS digunakan untuk memberikan penugasan dan evaluasi terhadap capaian pembelajaran. Pada akhir proses pembelajaran, mahasiswa diminta mengisi kuisioner. Kuisioner yang diajukan akan menghasilkan data mengenai application-computer selfefficacy, usia, latar belakang pendidikan menengah, dan kendala selama menggunakan LMS dalam pembelajaran.

\section{Instrumen Penelitian}

Instrumen yang digunakan adalah kuisioner tertutup dan terbuka (campuran). Kuisioner terbuka ketika mahasiswa mengisi jawaban sesuai kondisi mereka dan kuisioner tertutup dimana mahasiswa memilih jawaban yang tersedia. Instrumen lain yang digunakan adalah soal UTS dan UAS perkuliahan Matematika Diskrit yang berbentuk essay.

\section{Teknik Pengambilan Data}

Data yang digunakan dalam penelitian ini adalah data hasil akhir evaluasi belajar mahasiswa mata kuliah Kalkulus, Aljabar Linier dan Matematika Diskrit, rekapitulasi data kuisioner. Data yang diperlukan dalam penelitian selain diperoleh dari hasil tabulasi jawaban mahasiswa terhadap 
kuisioner, juga didapatkan dari database nilai akhir mahasiswa angkatan 2017 untuk perkuliahan Kalkulus dan Aljabar Linier pada dua semester sebelumnya. .

Mata kuliah Kalkulus dan Aljabar Linier digunakan untuk mengetahui kemampuan matematika mahasiswa sebelum mengikuti perkuliahan Matematika Diskrit. Kemampuan matematika mahasiswa diawal dikategorikan menjadi 4 kelompok yaitu Sangat Baik (SB), Baik (B), Cukup (C) dan Kurang (K). Kemampuan matematika mahasiswa diprediksi dapat mempengaruhi kemampuan mahasiswa memahami materi-materi Matematika Diskrit baik yang didistribusikan melalui LMS maupun yang diperoleh pada sesi tatap muka,

\section{Teknik Analisis Data}

Analisa data dilakukan menggunakan metode Regresi Dummy dengan bantuan software SPSS 25 . Regresi adalah salah satu metode analisa data paling mudah dan secara luas digunakan dalam penelitian kuantitatif. Regresi Dummy adalah pengembangan metode regresi yang mampu menganalisa variabel kualitatif yang tidak dapat diolah menggunakan regresi biasa. Regresi Dummy memungkinkan keberadaan variabel independen dengan bentuk data kategorikal sehingga dapat diolah dan diinterpretasikan. Dalam Regresi Dummy, variabel kategorikal dengan k kategori akan dibuat menjadi variabel dummy sebanyak k-1 variabel. Satu kategori dalam regresi dummy harus dijadikan sebagai reference category yang tidak diikutsertakan kedalam model namun dijadikan sebagai variabel pembanding. Setiap variabel dummy berelasi terhadap satu buah kategori dari variabel independen.

Nilai tiap responden dalam variabel dummy adalah 1 atau 0 . Nilai ini tergantung dari keanggotaannya dalam suatu variabel kategori. Jika seorang responden menjadi anggota dari suatu variabel dummy maka diberi nilai 1 dan sebaliknya diberi nilai 0 .

Misalkan Y adalah variabel dependen dan $\mathrm{D}_{1}, \mathrm{D}_{21}$, dan $\mathrm{D}_{22}$, masingmasing adalah variabel dummy dengan kategori $\mathrm{D}_{1}$ adalah 2 dan kategori $\mathrm{D}_{2}$ adalah 3 sehingga dibuat variabel dummy $\mathrm{D}_{21}$ dan $\mathrm{D}_{22}$. Maka dapat hubungan $\mathrm{Y}$ dengan beberapa variabel dummy dinyatakan dalam model berikut.

$Y_{i}=B_{0}+B_{1} D_{1 i}+B_{2} D_{21 i}+B_{3} D_{22 i}+\varepsilon_{i}$

$\mathrm{B}_{1}, \mathrm{~B}_{2}$, dan $\mathrm{B}_{3}$ menyatakan koefisien dari variable dummy $\mathrm{D}_{1}, \mathrm{D}_{21}$, dan $\mathrm{D}_{22}$. Nilai $B_{0}$ menyatakan nilai intersep yaitu nilai $Y$ ketika semua variabel dummy bernilai $0 . \quad$ Nilai $\varepsilon_{i}$ menyatakan error/kesalahan stokastik dari model regresi dummy.

Analisa data regresi dummy menggunakan SPSS 25, menurut (Landau \& Everitt, 2004) dapat menggunakan analisa multiple linier regression. Berikut beberapa jenis uji yang digunakan untuk menganalisa model regresi dummy pada persamaan (1).

Uji Korelasi dan Uji Korelasi Parsial 
Uji korelasi digunakan untuk mengukur asosiasi antar variabel dalam sebuah model regresi. Uji korelasi parsial digunakan untuk melihat hubungan variabel independen terhadap variabel dependen secara parsial. Artinya dapat dilihat variable independen yang paling kuat mempengaruhi variable dependen. Korelasi yang digunakan adalah korelasi Product Moment.

Ditentukan pula nilai $\mathrm{R}$, sebagai koefisien korelasi multiple dan $\mathrm{R}^{2}$ yang menyatakan tingkat keeratan hubungan nilai variable dependen yang diamati dengan yang diprediksi oleh model regresi.

\section{Uji Kecocokan Model}

Uji kecocokan model menggunakan nilai $F$ untuk menguji hipotesa null. Hipotesa null menyatakan bahwa tidak satupun variabel independen dalam model regresi yang berelasi dengan variabel dependen. Jika nilai $F_{\text {hitung }}>F_{\text {tabel }}$ dengan sig $<0.05$ maka dapat disimpulkan bahwa paling tidak terdapat satu variabel independen yang mempengaruhi variabel dependen. Uji t

Uji t terhadap koefisien regresi suatu variable dummy dilakukan untuk menguji tingkat signifikansi efek sebuah variable dummy dalam kategori yang telah didesain (Hardy, 1993). Jika nilai sig $<0.005$ dapat dikatakan suatu variabel independen memiliki pengaruh terhadap variabel dependen.

\section{Uji Heteroskedastisitas}

Uji heteroskedastisitas digunakan untuk mengetahui ada atau tidaknya ketaksamaan varians dari residual untuk semua pengamatan pada model regresi. Jika terjadi heteroskedastisitas, maka model regresi akan menghasilkan standard error yang salah sehingga akan membawa kepada kesimpulan akhir yang tidak tepat mengenai model regresi yang digunakan, misalnya gagal untuk menolak hipotesis null.

\section{Uji Multikolinieritas}

Uji multikolinieritas digunakan untuk memastikan tidak ada hubungan yang kuat antar variabel independen dlaam sebauh model regresi. Indikator multikolinieritas dapat dilihat dari nilai VIF dan Tolerance dengan ketentuan VIF $<10$ dan Tolerance $>0.1$.

\section{Uji Autokorelasi}

Uji autokorelasi dilakukan untuk memastikan bahwa tidak terdapat korelasi antara residual pada satu pengamatan dengan pengamatan lain pada model regresi. Metode yang digunakan adalah uji Durbin Watson dengan ketentuan suatu model regresi dikatakan mengalami autokorelasi jika $\mathrm{d}_{\mathrm{w}}<\mathrm{dL}$ atau $\mathrm{d}_{\mathrm{w}}>4$-dL. Jika dU $<\mathrm{d}_{\mathrm{w}}<$ 4-dU maka hipotesis null diterima yaitu tidak terjadi autokorelasi dalam model regresi.

\section{Uji Normalitas}

Suatu model regresi dikatakan baik atau layak jika memiliki residual yang berdistribusi normal. Maka uji normalitas dilakukan terhadap residual data model regresi menggunakan uji Kolmogorov Smirnov. Jika nilai D absolute < nilai kritis Kolmogorov Smirnov, maka residual dapat dikatakan berdistribusi normal. 


\section{HASIL DAN PEMBAHASAN}

Berdasarkan tabulasi data kuisioner, berikut disajikan karakteristik responden pada penelitian ini. Perhatikan bahwa sebagian besar responden telah berpengalaman menggunakan LMS dalam proses pembelajaran dan responden adalah fresh graduate ketika mendaftarkan diri sebagai mahasiswa. Maka berdasarkan data tersebut, dapat dikatakan bahwa populasi homogen. Sebanyak 40.196\% responden merasa terkendala dalam penggunaan LMS karena bandwidth system yang belum cukup memadai. $25.49 \%$ terkendala karena biaya ketika mengakses LMS dari luar kampus. Sisanya, sebanyak $20.588 \%$ responden kurang berminat belajar matematika dengan LMS dan $13.725 \%$ malas belajar. Kendala lain yang mungkin ada tidak dikaji dalam penelitian ini.

Selanjutnya, berdasarkan hasil analisa data, diperoleh nilai $\mathrm{R}$ sebesar 0,605 seperti pada Tabel 2, artinya terdapat korelasi yang sangat kuat antara variable yang diobservasi yaitu $Y$ dengan variable-variabel independen yang diprediksi dalam model regresi. Standar error digunakan untuk mengukur perbedaan antara $\mathrm{Y}$ dengan rata-rata $\mathrm{Y}$ dari responden dengan $\mathrm{KM}$ (variable dummy SB,B), ACSE (variable dummy ST,T) dan LBP (variable dummy SMA) yang sama pada populasi penelitian ini.

Tabel 1. Karakteristik Responden

\begin{tabular}{llll}
\hline Variabel Independen & Kategorisasi & Jumlah & Persentase \\
\hline Asal Sekolah & SMA/MA & 58 & 56.86 \\
& Non SMA/MA & 44 & 43.14 \\
Jenis Kelamin & Laki-Laki & 70 & 68.63 \\
& Perempuan & 32 & 31.37 \\
ACSE & Tinggi & 6 & 0.0588 \\
& Sedang & 87 & 85.294 \\
Status saat PMB & Rendah & 9 & 0.088 \\
Pengalaman & Fresh Grad & 88 & 86.275 \\
Menggunakan LMS & Bukan Fresh Grad & 14 & 13.725 \\
Kendala & Pernah & 87 & 85.294 \\
Menggunakan LMS & Tidak Pernah & 15 & 14.706 \\
& Bandwidth & 41 & 40.196 \\
& Biaya & 26 & 25.49 \\
& Minat & 21 & 20.588 \\
\hline
\end{tabular}

Estimasi nilai standard error model yaitu sebesar 4.412. Pada Tabel 2 juga disajikan nilai adjusted $\mathrm{R}^{2}=$
0.580 , artinya $58 \%$ varians dapat diprediksi dari variabel dummy dalam model regresi.

Tabel 2. Koefisien Determinasi

\begin{tabular}{lllll}
\hline Model & $\mathrm{R}$ & $\mathrm{R}$ Square & Adjusted R Square & Std.Error of the Estimate \\
\hline 1 & 0.778 & 0.605 & 0.580 & 4.412 \\
\hline
\end{tabular}


a. Predictors : (Constant), SMA, C, SB, T,ST,B

Berdasarkan Tabel 3, diperoleh nilai $\left(\mathrm{F}(6,95)=24.267>\mathrm{F}_{\text {tabel }}=2.20\right.$, $\rho<0.001)$, artinya kombinasi variabelvariabel dummy secara signifikan memprediksi variabel Y.
Berdasarkan nilai tersebut, kita dapat menolak hipotesa null yang menyatakan tidak ada variabel dummy yang berkaitan atau mempengaruhi variabel dependen Y.

Tabel 3. ANOVA

\begin{tabular}{|c|c|c|c|c|c|c|}
\hline \multicolumn{2}{|c|}{ Model } & Sum of Squares & $\mathrm{df}$ & Mean Square & $\mathrm{F}$ & Sig \\
\hline \multirow[t]{3}{*}{1} & Regression & 2834.217 & 6 & 472.369 & 24.267 & 0.000 \\
\hline & Residual & 1849.244 & 95 & 19.466 & & \\
\hline & Total & 4683.461 & 101 & & & \\
\hline
\end{tabular}

a. Dependent Variable : Y

b. Predictors : (constant), SMA,C,SB,T,ST,B

Tabel 4. Koefisien Variabel Dummy

\begin{tabular}{llllll}
\hline $\begin{array}{l}\text { Model } \\
1\end{array}$ & \multicolumn{2}{l}{$\begin{array}{l}\text { Unstandardized } \\
\text { Coefficiant }\end{array}$} & $\begin{array}{l}\text { Standardized } \\
\text { Coefficients }\end{array}$ & T & Sig \\
& B & Std Error & Beta & & \\
\hline Constant & 65.601 & 2.342 & & 28.005 & 0.000 \\
SB & 15.228 & 2.731 & 0.436 & 5.575 & 0.000 \\
B & 1.964 & 2.110 & 0.143 & 0.931 & 0.354 \\
C & -2.555 & 2.151 & -0.188 & -1.188 & 0.238 \\
ST & 8.797 & 1.817 & 0.505 & 4.841 & 0.000 \\
T & 3.900 & 1.464 & 0.262 & 2.664 & 0.009 \\
SMA & 3.075 & 0.901 & 0.225 & 3.412 & 0.001 \\
\hline
\end{tabular}

Pada Tabel 4, diperoleh nilai responden dengan kemampuan

koefisien untuk masing-masing variable matematika Sangat Baik (SB)

dummy. Sehingga diperoleh model dibandingkan dengan responden dengan regresi dummy :

$Y=65.601+15.228 D_{11}+$

$1.964 D_{12}-2.555 D_{13}+8.797 D_{21}+$

$3.900 D_{22}+3.075 D_{3}+\varepsilon$.

Perhatikan bahwa nilai koefisien regresi untuk variabel $\mathrm{C}$ adalah -2.555 . Prediksi Y berdasarkan C lebih sedikit dibandingkan dengan prediksi dari variabel $\mathrm{K}$ sebagai reference category. Nilai koefisien regresi pada variable dummy diatas menyatakan perbedaan nilai Y karena kenaikan 1 unit variable dummy dan nilai $\mathrm{Y}$ berdasarkan reference category. Misalkan $\mathrm{Y}$ akan berubah sebesar 15,229 untuk kemampuan Kurang (K) dimana K adalah reference category.

Perhatikan pula bahwa, nilai koefisien regresi untuk variable dummy Sangat Tinggi (ST), yang merujuk kepada variable ACSE mampu menaikkan sebesar variabel $\mathrm{Y}$ sebesar 8.797 dibandingkan dengan reference category yaitu ACSE Rendah (R). Selanjutnya variable SMA lebih besar 3.075 menaikkan variable $\mathrm{Y}$ dibandingkan variabel NonSMA yang menjadi reference category.

Nilai t dan level signifikan pda Tabel 4 untuk setiap variabel 
mengindikasikan bahwa variabel dummy SB, ST dan SMA signifikan berkontribusi dalam model regresi untuk memprediksi nilai variabel dependen $\mathrm{Y}$ bila dibandingkan dengan variabel dummy yang lain.

Selanjutnya, perhatikan bahwa Tabel 5 menunjukan korelasi yang kuat antara $\mathrm{Y}$ dan variabel semua variabel dummy. Namun hubungan $\mathrm{Y}$ dengan $\mathrm{C}$ dan $\mathrm{T}$ dikatakan kuat tidak searah. Artinya meningkatnya nilai $\mathrm{C}$ maupun $\mathrm{T}$ akan menurunkan nilai $\mathrm{Y}$. Berdasarkan hasil pengolahan data perhatikan bahwa semua variabel dummy signifikan karena sig $<0.05$.

Perhatikan pula sebagian besar koefisien korelasi antar beberapa variabel independen dalam model tak searah. Hanya nilai korelasi antara variabel B dan ST (0.458), serta C dan $\mathrm{T}$ (0.426) yang menunjukan koefisien korelasi yang cukup besar, searah dan signifikan. Artinya Kemampuan Matematika berkorelasi terhadap ACSE. Namun koefisien korelasi antar variabel dummy tersebut belum dapat menggambarkan dengan jelas apakah ST dan B, serta $\mathrm{C}$ dan $\mathrm{T}$ benar-benar memepengaruhi Y. Maka diperlukan analisa korelasi parsial antara setiap variabel dummy dengan Y..

Dalam rangka menguraikan hubungan parsial variabel-variabel independen dengan variabel dependennya digunakan uji korelasi parsial. Berdasarkan data Tabel 6 diperoleh nilai koefisien korelasi masing-masing variabel dummy secara parsial terhadap variabel dependen $\mathrm{Y}$. Koefisien untuk masing-masing variabel dummy menunjukan hubungan yang positif dengan variabel dependen Y.

Tabel 5. Korelasi Antar Variabel

\begin{tabular}{|c|c|c|c|c|}
\hline \multicolumn{2}{|c|}{ Variabel } & \multirow{2}{*}{$\begin{array}{l}\begin{array}{l}\text { Pearson } \\
\text { Corelation }\end{array} \\
0.512 \\
0.419 \\
-0.548 \\
0.511 \\
-0.316 \\
0.192\end{array}$} & \multirow{2}{*}{\begin{tabular}{|l|} 
Sig (1 -tailed) \\
0.000 \\
0.000 \\
0.000 \\
0.000 \\
0.001 \\
0.026 \\
\end{tabular}} & $\mathbf{N}$ \\
\hline $\mathrm{Y}$ & $\begin{array}{l}\text { SB } \\
\text { B } \\
\text { C } \\
\text { ST } \\
\text { T } \\
\text { SMA }\end{array}$ & & & \multirow{5}{*}{102} \\
\hline SB & $\begin{array}{l}\text { B } \\
\text { C } \\
\text { ST } \\
\text { T } \\
\text { SMA } \\
\end{array}$ & $\begin{array}{l}-0.07 \\
-0.214 \\
0.163 \\
-0.202 \\
0.074 \\
\end{array}$ & $\begin{array}{l}0.242 \\
0.015 \\
0.051 \\
0.021 \\
0.230 \\
\end{array}$ & \\
\hline B & $\begin{array}{l}\text { C } \\
\text { ST } \\
\text { T } \\
\text { SMA }\end{array}$ & $\begin{array}{l}-0.866 \\
0.458 \\
-0.320 \\
-0.018\end{array}$ & $\begin{array}{l}0.000 \\
0.000 \\
0.001 \\
0.428\end{array}$ & \\
\hline $\mathrm{C}$ & $\begin{array}{l}\mathrm{ST} \\
\mathrm{T} \\
\text { SMA }\end{array}$ & $\begin{array}{l}-0.507 \\
0.426 \\
0.012\end{array}$ & $\begin{array}{l}0.000 \\
0.000 \\
0.454\end{array}$ & \\
\hline ST & $\mathrm{T}$ & -0.741 & 0.000 & \\
\hline
\end{tabular}




\begin{tabular}{l|l|l|l}
\hline & SMA & -0.143 & 0.076 \\
\hline $\mathrm{T}$ & SMA & 0.046 & 0.323 \\
\hline
\end{tabular}

Berdasarkan hasil pada Tabel 6 menunjukan bahwa koefisien korelasi parsial bernilai positif untuk variabel SB, B, ST dan SMA terhadap nilai variabel Y.
Selanjutnya untuk memastikan bahwa tidak terjadi multikolinieritas antar variabel independen dalam model, perhatikan nilai VIF pada Tabel 7.

Tabel 6. Korelasi Parsial

\begin{tabular}{l|l|l|l}
\hline Model 1 & Zero-order & Partial & Part \\
\hline SB & 0.512 & 0.497 & 0.359 \\
B & 0.419 & 0.095 & 0.060 \\
C & -0.548 & -0.121 & -0.077 \\
ST & 0.511 & 0.445 & 0.312 \\
T & -0.316 & 0.264 & 0.172 \\
SMA & 0.192 & 0.330 & -.220 \\
\hline
\end{tabular}

Dependent Variable : Y

Perhatikan bahwa semua nilai VIF setiap variabel dummy $<10$ dan nilai Tolerance $>0.1$, artinya tidak terjadi multikolinieritas dalam model regresi. Kemudian, berdasarkan hasil uji heteroskedastisitas pada Tabel 8, diperoleh nilai sig > 0.05 untuk semua variabel dummy. Dengan demikian tidak terjadi heteroskedastisitas pada model regresi dummy.

Tabel 7. Uji Multikolinieritas

\begin{tabular}{l|l|l}
\hline \multirow{2}{*}{$\begin{array}{l}\text { Model } \\
\text { Constant }\end{array}$} & Colinearity Statistics \\
\cline { 2 - 3 } Soelance & VIF \\
SB & & \\
B & 0.679 & 1.473 \\
C & 0.176 & 5.687 \\
ST & 0.166 & 6.040 \\
T & 0.381 & 2.623 \\
SMA & 0.429 & 2.332 \\
\hline
\end{tabular}

Tabel 8 Uji Heteroskedastisitas

\begin{tabular}{l|l|l|l|l|l}
\hline Model 1 & B & Std Error & Beta & T & Sig \\
\hline Constant & 2.249 & 1.454 & & 1.547 & 0.125 \\
SB & -0.913 & 1.695 & -0.066 & -0.539 & 0.591 \\
B & 0.120 & 1.309 & 0.022 & 0.092 & 0.927 \\
C & -0.260 & 1.335 & -0.048 & -0.195 & 0.846 \\
ST & 1.305 & 1.128 & 0.189 & 1.157 & 0.250 \\
T & 0.857 & 0.908 & 0.145 & 0.944 & 0.348 \\
SMA & 0.576 & 0.559 & 0.106 & 1.029 & 0.306 \\
\hline
\end{tabular}

Dependent Variable: RES2 
Berdasarkan uji Kolmogorov Smirnov, diperoleh nilai $\mathrm{D}$ absolute yaitu $0.090<\mathrm{D}_{\text {tabel }}=0.14824$ dengan sig $0.04>0.01$. Dengan demikian dapat disimpulkan residual berdistribusi normal implikasinya model regresi dikatakan baik.

Berikutnya dilakukan uji autokorelasi menggunakan metode uji Durbin Watson. Berdasarkan hasil pengolahan data dipeorleh hasil $\mathrm{dw}=$ 1.971. Berdasarkan table Durbin Watson dengan $\mathrm{k}=6$ dan $\mathrm{n}=102$ diperoleh nilai $\mathrm{dL}=1.5552$ dan $\mathrm{dU}=$ 1.8035. Sehingga dihasilkan nilai 4-dU $=2.1965$. Maka dU=1.8035 $<\mathrm{dw}=$ $1.971<4-\mathrm{dU}=2.1965$. Dengan demikian dapat disimpilkan tidak terjadi autokorelasi dalam model regresi.

Berdasarkan uji yang telah dilakukan dapat disimpulkan bahwa model regresi dummy layak untuk mengestimasi koefisien regresi dari variabel-variabel dummy. Dengan demikian estimasi koefisien regresi variabel-variabel dummy dapat digunakan untuk memprediksi nilai variabel Y.

Variabel-variabel independen berupa Kemampuan Matematika, ACSE, dan Latar Belakang Pendidikan (sebelum perguruan tinggi) berpengaruh siginifikan terhadap keberhasilan mahasiswa dalam proses pembelajaran Matematika Diskrit yang menggunakan LMS sebagai system pendukung. Hasil penelitian ini sejalan dengan kajiankajian sebelumnya.

$$
\text { Kajian sebelumnya dari }
$$
(Baragash \& Al-Samarraie, 2018) dan (Lin, Chen, \& Liu, 2017) menyimpulkan bahwa LMS dan pembelajaran digital berperan signifikan terhadap perfoma akhir mahasiswa. Ada faktor-faktor yang menentukan keberhasilan penggunaan LMS dalam proses pembelajaran. (Broadbent, 2016) menyatakan self-efficacy berperan signifikan terhadap keberhasilan proses belajar dengan LMS sebagai system pendukung, sedangkan (Wardsworth dkk, 2007) menyatakan bahwa pencapaian dalam pembelajaran matematika secara online ditentukan oleh self-efficacy dan stretegi belajar. (Santoso,dkk 2014) menyatakan bahwa siswa dengan computer self-efficacy yang tinggi lebih mudah beradaptasi dengan model pembelajaran berbasis web.

(Nizoloman, 2013) menyatakan keberhasilan siswa dalam pembelajaran matematika dipeengaruhi oleh kemampuan matematikanya. Sementara (Fan \& Li, 2002) menyatakan bahwa kemampuan matematika berpengaruh terhadap pencapaian akademik secara keseluruan seorang mahasiswa program studi ilmu komputer. Kajian lain melihat factor latar belakang pendidikan menengah berpengaruh terhadap kemampuan matematika. Seorang mahasiswa dengan latar belakang pendidikan SMA/MA akan memiliki pengalaman belajar matemtika lebih banyak dibandingkan dengan lulusan non-SMA/MA. Hal ini sesuai dengan riset yang dilakukan (Conn, dkk, 2018) dan (Ozdemir \& Onder-ozdemir, 2017). Kajian yang dilakukan (Orhun, 1994) menyimpulkan bahwa latar belakang pendidikan menengah mahasiswa berpengaruh terhadap performa mereka dalam mata kuliah kalkulus. 


\section{SIMPULAN DAN SARAN}

\section{Simpulan}

Berdasarkan hasil dan pembahasan di atas disimpulkan bahwa kemampuan matematika dan level ACSE mahasiswa berpengaruh postitif dan signifikan terhadap kualitas hasil proses pembelajaran Matematika Diskrit yang menggunakan LMS sebagai sistem pendukung.

\section{Saran}

Perlu kajian lebih lanjut mengenai faktor-faktor lain yang mungkin berpengaruh terhadap keberhasilan pemanfaatan LMS baik pada mata kuliah Matematika Diskrit maupun pada semua mata kuliah disuatu program studi yang sama.

Penelitian selanjutnya dapat pula mengkaji pemanfaatan LMS sebagai sistem pendukung proses pembelajaran di perguruan tinggi dengan memperhatikan lebih dalam kebutuhan dan karakteristik mahasiswa.

\section{DAFTAR PUSTAKA}

Ayub,et. al. (2010). Factors influencing students $^{\text {ee }}$ use a Learning Management System portal: Perspective from higher education students. International Journal of Education and Information Technologies, 2, 4-8.

Bandura, A. (1994). Self-efficacy. In V. S. Ramachaudran (Ed.), Encyclopedia of human behaviour (Vol. 4, pp. 71-81). New York: Academic Press.

Baragash, R.S., \& Al-Samarraie, H., (2018). Blended learning: Investigating the influence of engagement in multiple learning delivery modes on students' performance. Telematics and Informatics.doi $:$ :10.1016/j.tele.2018.07.010

Broadbent, J. (2016). Academic success is about self-efficacy rather than frequency of use of the learning management system. Australasian Journal of Educational Technology, 32(4), 38-49.

Conn, K. M., Birnie, C., McCaffrey, D., \& Brown, J. (2018). The relationship between prior experiences in mathematics and pharmacy school success. American Journal of Pharmaceutical Education, 82(4), 6257.

Carmean, C. \& Haefner, J. (2002). Mind over matter : Transforming course management systems into effective learning environments. EDUCAUSE Review, 37(6), 2734.

Coates, H., James, R., \& Baldwin, G. (2005). A critical examination of the effects of learning management systems on university teaching and learning. Tertiary Education and Management, 11, 19-36.

Degeng. (2004). Teori Pembelajaran, Malang : UM Press.

Fan, T., \& Li, Y. (2002). Is math ability beneficial to performance in college computer science programs. Journal of National Taipei Teachers College, 15(1), 69-98.

Hardy, M. (1993). Regression With Dummy Variables, Series : Quantitative Application In The Social Sciences. California : Sage Pub.

İlker, (2014). Study of the correlation between academic achievement and interaction preferences of 
online learners. USTA International Journal of Business and Social Science. 5(5)

Karsenty, R. (2014). Mathematical Ability. Lerman S Encyclopedia of Mathematics Education. Dordrecht : Springer.

Koshy. V, Ernest, P., \& Casey R (2009). Mathematically gifted and talented learners : theory and practice. Int.J Math. Edu. Sci. Techno, 40(2), 213-228.

Landau, Sabine \& Everitt, B. (2004). Handbook of Statistical Analyses Using SPSS. Florida : Chapman Hall/CRC.

Lin, M. H., Chen, H. C., \& Liu, K. S. (2017). A study of the effects of digital learning on learning motivation and learning outcome. Eurasia Journal of Mathematics, Science and Technology Education, 13(7), 3553-3564.

Marakas, G.M., Yi, M.Y., \& Johnson, R.D., (1998). The multilevel and multifaceted character of computer self-efficacy: toward clarification of the construct and an integrative framework for research. Information Systems Research, 9, 126-163.

Nizoloman, O. N. (2013). Relationship between mathematical ability and achievement in mathematics among female secondary school students in Bayelsa State Nigeria. Procedia - Social and Behavioral Sciences, 106, 2230-2240.

Orhun, N. (1994). The Effects of general matematics in High School, 90(1), 1-3.

Ozdemir, H., \& Onder-ozdemir, N. (2017) Vocational high school students perceptions of success in mathematics. Int. Elecronic Journal of Math. Edu, 12 (3), 493-502.
Santoso, H. B., Lawanto, O., Becker, K., Fang, N., \& Reeve, E. M. (2014). High and low computer self-efficacy groups and their learning behavior from selfregulated learning perspective while engaged in interactive learning modules. Journal of PreCollege Engineering Education Research, 4(2), 11-28.

Stith, B. (2000). Web-enhanced lecture course scores big with students and faculty. THE Journal (Technological Horizons in Education), 27 (8), 20.

Sturgess, G.(2012). Skills vs competencies. What's the difference? Talent Align. [online] www.talentalign.com.

Wadsworth, M., Husman, J., Duggan, M.A., and Pennington, M.N. (2007). Online mathematics achievement: Effects of learning strategies and self-efficacy Journal Developmental Education, 30( 3) , 6-14.

Williams, D., \& Whiting, A. (2016) Exploring the relationship between student engagement, twitter, and a learning management system: A study of undergraduate marketing students. International Journal of Teaching and Learning in Higher Education. 28 (3), 302-313.

Yi, M. Y., \& Hwang, Y. (2003). Predicting the use of web-based information systems: Selfefficacy, enjoyment, learning goal orientation, and the technology acceptance model. International Journal of Human Computer Studies, 59(4), 431-44. 